\title{
Isolation of soybean mutants with high and low inorganic phosphorus
}

\author{
Jagadeesh Sundaramoorthy ${ }^{1} \cdot$ Yean Joo Seo $^{2} \cdot$ Gyu Tae Park ${ }^{1}$. \\ Jeong-Dong Lee ${ }^{1} \cdot$ Soon-Ki Park ${ }^{1} \cdot$ Hak Soo Seo ${ }^{3} \cdot$ Jong Tae Song $^{1}$
}

Received: 18 May 2016 / Accepted: 15 June 2016 / Published Online: 30 September 2016

(C) The Korean Society for Applied Biological Chemistry 2016

\begin{abstract}
In soybean (Glycine max (L.) Merr.) seeds, phosphorus $(\mathrm{P})$ is primarily stored in the form of phytate, which is generally indigestible by monogastric animals such as human, pig, poultry, and fish. Thus, this study was conducted to isolate soybean mutants with high available P. Inorganic P content was assessed in a total of 1,266 ethyl methanesulfonate (EMS) $\mathrm{M}_{4}$ lines from the Pungsannamul cultivar. Among the tested lines, four EMS lines (PE379, PE432, PE2205, and PE2503) showed higher mean inorganic $\mathrm{P}\left(1.21-1.56 \mathrm{~g} \mathrm{~kg}^{-1}\right)$ than did the Pungsannamul cultivar $\left(0.90 \mathrm{~g} \mathrm{~kg}^{-1}\right)$. Additionally, six EMS lines (PE718, PE828, PE1466, PE1552, PE3378, and PE3386) showed lower mean inorganic $\mathrm{P}\left(0.38-0.60 \mathrm{~g} \mathrm{~kg}^{-1}\right)$. The high inorganic $\mathrm{P}$ mutants isolated in this study will be further investigated for phytate and total P levels. Moreover, the high and low inorganic $\mathrm{P}$ lines will be utilized in a future study of the biochemical pathway of phytate.
\end{abstract}

Keywords Glycine max · Inorganic phosphorus - Phytate Soybean

Jong Tae Song $(\bowtie)$

E-mail: jtsong68@knu.ac.kr

${ }^{1}$ School of Applied Biosciences, Kyungpook National University, Daegu, Republic of Korea

${ }^{2}$ Institute of Agricultural Science and Technology, Kyungpook National University, Daegu, Republic of Korea

${ }^{3}$ Department of Plant Bioscience, Seoul National University, Seoul, Republic of Korea

This is an Open Access article distributed under the terms of the Creative Commons Attribution Non-Commercial License (http://creativecommons. org/licenses/by-nc/3.0/) which permits unrestricted non-commercial use, distribution, and reproduction in any medium, provided the original work is properly cited.

\section{Introduction}

Plant seeds accumulate phosphorus $(\mathrm{P})$ primarily in the form of phytic acid (myo-inositol 1,2,3,4,5,6-hexakisphosphate; Gillman et al. 2009). The phytic acid is found chelated with cationic minerals, thereby reducing availability of $\mathrm{Ca}, \mathrm{Mg}, \mathrm{Fe}$, and $\mathrm{Zn}$ in the form of phytate (Brown and Solomons 1991; Mendoza et al. 1998; Raboy 2002; Bilyeu et al. 2008). Phytate is detected in most economically important crops such as soybean, Jatropha, wheat, barley, maize, groundnut, rapeseed, sunflower, niger, and poppy (Eklund 1975; Platt and Clydesdale 1987; Fredlund et al. 1997; Wilcox et al. 2000; Mendoza et al. 2001; Makkar and Becker 2009; Hande et al. 2013). However, monogastric animals such as human, pig, poultry, and fish have limited ability to digest and utilize phytate (Brinch-Pedersen et al. 2002). The undigested and excreted phytate, in turn, causes water pollution and eutrophication in the environment (Gillman et al. 2009; Hande et al., 2013). Most phosphorus content in soybean (Glycine max (L.) Merr.) seeds is in the form of phytate (65-85\%), leading to a deficiency in available P (Bilyeu et al. 2008). Therefore, soybean meal is usually enhanced with supplemental mineral $\mathrm{P}$ and/or phytase enzyme to increase the availability of P (Adeola et al. 1995; Almeida et al. 2013).

Research on development of soybean mutants with low phytate has been conducted after improvement of a simple and rapid assay to evaluate inorganic P (Wilcox et al. 2000; Hitz et al. 2002). Wilcox et al. (2000) developed two independent soybean mutants, M153 and M766, by mutagenesis using ethyl methanesulfonate (EMS). Both EMS lines showed an increase in inorganic P and decrease in phytate. The M153 line had the highest levels of inorganic $\mathrm{P}$ and was extensively used in development of several independent breeding lines such as the CX1834 series (CX18341-2, CX1834-1-3, and CX1834-1-6; Oltmans et al. 2004; Walker et al. 2006). Similar mutants with high inorganic $P$ and low phytate were produced in barley (Larson et al. 1998) and maize (Raboy et al. 2000).

Hitz et al. (2002) showed that the myo-inositol phosphate 
synthase 1 (MIPS1) gene was responsible for low levels of phytate in soybean mutant line LR33. However, sequence analysis of the MIPS gene and genetic mapping showed that it was not responsible for low phytate levels in another soybean mutant line, CX1834 (Chappell et al. 2006; Maroof et al. 2009). In a lowphytate mutant of maize (low phytic acid 1, lpal), a multidrug resistance-associated protein (MRP) ATP-binding cassette transporterencoding gene (MRP4) was identified as causative for the low phytate trait (Shi et al. 2007). This MRP4 gene was identified as most closely related to the MRP5 gene in Arabidopsis, which contains an integral transmembrane domain and a cystolic ATPbinding domain (Klein et al. 2006; Shi et al. 2007). In soybean, Gillman et al. (2009) identified two homologs of the maize MRP4 gene and Arabidopsis MRP5 gene: Glyma03g32500 (lpal) and Glyma19g35230 (lpa2). They also discovered two independent mutations in the CX1834 mutant line with two recessive alleles (a nonsense mutation in the lpal-a and a missense mutation in lpa2a). Analysis for inorganic P in CX1834 showed an association between homozygosity for the lpal-a and lpa2-a mutations and increased levels of inorganic P. In addition, another novel allele with a nonsense mutation (lpa2-b) was identified in the M766 mutant (Gillman et al. 2009).

The objective of this study was to isolate soybean mutants with increased available inorganic $\mathrm{P}$ in EMS mutant lines derived from the cultivar Pungsannamul. Further, genetic and molecular analyses of high and low inorganic P (HIP and LIP, respectively) mutant lines will be helpful in understanding the phytate biochemical pathway.

\section{Materials and Methods}

\section{Plant materials}

To test the inorganic $\mathrm{P}$ trait, a total of $1,266 \mathrm{M}_{4}$ EMS lines were produced from a single $\mathrm{M}_{3}$ plant of each line derived from the Pungsannamul cultivar (Lee et al. 2015; Table 1). Cultivars Pungsannamul, Williams 82, and the high inorganic P mutant 5601T-1316 (developed from the CX1834 series, CX1834-1-2 X $5601 T$ ) were used as controls. Individual seeds of four HIP (PE379, PE432, PE2205, and PE2503) and six LIP (PE718, PE828, PE1466, PE1552, PE3378, and PE3386) mutant lines were analyzed for inorganic $\mathrm{P}$ level (Table 2).

\section{Colorimetric method for inorganic phosphate determination}

Inorganic P content was quantified using the modified method described by Wilcox et al. (2000). Three to four seeds of each line $(0.5 \mathrm{~g}$ in total) were crushed with a hammer and extracted overnight with vigorous stirring in $5 \mathrm{~mL}$ of extraction buffer (12.5 $\%$ [w/v] trichloroacetic acid in $25 \mathrm{mM} \mathrm{MgCl}_{2}$ ). After allowing particulates to settle, $1 \mathrm{~mL}$ of seed extract was centrifuged at $11,269 \mathrm{~g}$ for $10 \mathrm{~min}$. The assay $(1000 \mu \mathrm{L}$ total volume) was prepared by combining a $60 \mu \mathrm{L}$ aliquot of the seed extract, $690 \mu \mathrm{L}$

Table 1 Inorganic $\mathrm{P}$ content in lines of an EMS treated population of Pungsannamul (with $0.90 \pm 0.05 \mathrm{~g} \mathrm{~kg}^{-1}$ inorganic P)

\begin{tabular}{lccccccccc}
\hline Inorganic $\mathrm{P}\left(\mathrm{g} \mathrm{kg}^{-1}\right)$ & $0.40 \sim 0.50$ & $\sim 0.60$ & $\sim 0.70$ & $\sim 0.80$ & $\sim 0.90$ & $\sim 1.00$ & $\sim 1.10$ & $\sim 1.20$ & $\sim 1.30$ \\
\hline No. of lines (Total 1,266) & 6 & 73 & 303 & 200 & 368 & 219 & 83 & 8 & 4 \\
\hline
\end{tabular}

Table 2 Inorganic $\mathrm{P}$ content $\left(\mathrm{g} \mathrm{kg}^{-1}\right)$ of individual seeds from each mutant line isolated with low and high inorganic $\mathrm{P}$

\begin{tabular}{|c|c|c|c|c|c|c|c|c|c|c|c|c|c|}
\hline 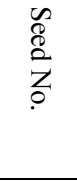 & $\underset{\infty}{\stackrel{\vec{T}}{J}}$ & $\begin{array}{l}\vec{T} \\
\mathbb{T} \\
\infty \\
\infty \\
\infty\end{array}$ & $\frac{\vec{\pi}}{\frac{\pi}{a}}$ & $\frac{\vec{N}}{\vec{N}}$ & 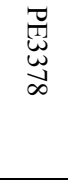 & $\begin{array}{l}\overrightarrow{\widetilde{T}} \\
\underset{\omega}{\omega} \\
\infty \\
\sigma\end{array}$ & $\underbrace{\vec{T}}_{\vec{\sigma}}$ & $\begin{array}{l}\vec{T} \\
\stackrel{+}{+} \\
\stackrel{N}{N}\end{array}$ & $\begin{array}{l}\vec{\nabla} \\
\text { N } \\
\text { N } \\
\text { Ui }\end{array}$ & 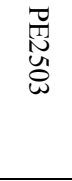 & 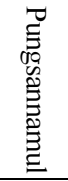 & 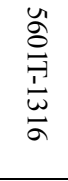 & 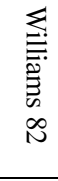 \\
\hline & \multicolumn{6}{|c|}{ Low inorganic $\mathrm{P}$ (LIP) } & \multicolumn{4}{|c|}{ High inorganic $\mathrm{P}$ (HIP) } & \multicolumn{3}{|c|}{ Controls } \\
\hline 1 & 0.59 & 0.43 & 0.27 & 0.48 & 0.43 & 0.63 & 2.43 & 2.43 & 1.90 & 1.73 & 1.08 & 2.96 & 0.89 \\
\hline 2 & 0.58 & 0.50 & 0.57 & 0.44 & 0.64 & 0.52 & 2.08 & 2.40 & 1.55 & 1.45 & 0.95 & 2.86 & 0.82 \\
\hline 3 & 0.58 & 0.56 & 0.48 & 0.42 & 0.51 & 0.61 & 1.88 & 1.83 & 1.48 & 1.26 & 0.94 & 2.86 & 0.80 \\
\hline 4 & 0.55 & 0.55 & 0.70 & 0.41 & 0.54 & 0.65 & 1.88 & 1.73 & 1.48 & 1.26 & 0.93 & 2.77 & 0.78 \\
\hline 5 & 0.55 & 0.63 & 0.38 & 0.40 & 0.53 & 0.79 & 1.61 & 1.61 & 1.44 & 1.19 & 0.91 & 2.71 & 0.78 \\
\hline 6 & 0.54 & 0.52 & 0.55 & 0.39 & 0.68 & 0.54 & 1.38 & 1.52 & 1.44 & 1.19 & 0.90 & 2.42 & 0.69 \\
\hline 7 & 0.53 & 0.64 & 0.55 & 0.39 & 0.44 & 0.62 & 1.32 & 1.45 & 1.30 & 1.19 & 0.89 & 2.38 & 0.64 \\
\hline 8 & 0.52 & 0.50 & 0.78 & 0.37 & 0.81 & 0.45 & 1.32 & 1.38 & 1.30 & 1.08 & 0.88 & 2.31 & 0.63 \\
\hline 9 & 0.51 & 0.47 & 0.63 & 0.37 & 0.68 & 0.63 & 1.26 & 1.33 & 1.26 & 1.06 & 0.86 & 2.25 & \\
\hline 10 & 0.51 & 0.50 & 0.52 & 0.34 & 0.61 & 0.37 & 1.19 & 1.08 & 1.21 & 1.06 & 0.85 & 2.25 & \\
\hline 11 & 0.50 & 0.51 & 0.42 & 0.29 & 0.46 & 0.62 & 1.19 & 1.04 & 0.97 & 1.01 & 0.83 & 2.17 & \\
\hline 12 & 0.49 & 0.53 & 0.44 & 0.28 & 0.54 & 0.79 & 1.03 & 1.00 & 0.97 & 1.00 & 0.77 & 1.99 & \\
\hline Mean & 0.54 & 0.53 & 0.52 & 0.38 & 0.57 & 0.60 & 1.55 & 1.56 & 1.36 & 1.21 & 0.90 & 2.49 & 0.75 \\
\hline $\mathrm{SD}^{*}$ & 0.03 & 0.06 & 0.13 & 0.06 & 0.11 & 0.12 & 0.41 & 0.45 & 0.24 & 0.20 & 0.07 & 0.31 & 0.09 \\
\hline
\end{tabular}

*SD, standard deviation 
of $\mathrm{ddH}_{2} \mathrm{O}$, and $250 \mu \mathrm{L}$ of colorimetric reagent (1 volume of $3 \mathrm{M}$ $\mathrm{H}_{2} \mathrm{SO}_{4}, 1$ volume of $0.02 \mathrm{M}$ ammonium molybdate tetrahydrate, 1 volume of $10 \%[\mathrm{v} / \mathrm{v}]$ ascorbic acid, and 2 volumes of $\mathrm{ddH}_{2} \mathrm{O}$ ). The assay mix was allowed to incubate at $40^{\circ} \mathrm{C}$ for $60 \mathrm{~min}$, and then absorbance was read at $655 \mathrm{~nm}$ in a Smartspec 3000 (BioRad, CA, USA). A standard curve was generated with P standards $(0.05 \mathrm{mg} / \mathrm{mL}$; Megazyme, Wicklow, Ireland). Inorganic P content was converted to $\mathrm{g} \mathrm{kg}^{-1}$ ( $\mathrm{g}$ of $\mathrm{P}$ per $\mathrm{kg}$ of seed).

\section{Results and Discussion}

Initial screening of inorganic $\mathrm{P}$ content in seeds identified four HIP $\left(>1.20 \mathrm{~g} \mathrm{~kg}^{-1}\right)$ and six LIP $\left(<0.60 \mathrm{~g} \mathrm{~kg}^{-1}\right)$ mutant lines among 1,266 $\mathrm{M}_{4}$ EMS lines when compared with Pungsannamul (0.90 g $\mathrm{kg}^{-1}$; Table 1). Individual seeds of each mutant line from initial screening were further tested to verify inorganic $\mathrm{P}$ content and to analyze homozygosity in part (Table 2). The four HIP (PE379, PE432, PE2205, and PE2503) mutant lines showed higher average values of inorganic $\mathrm{P}\left(1.55,1.56,1.36\right.$, and $\left.1.21 \mathrm{~g} \mathrm{~kg}^{-1}\right)$, corresponding to $72,73,51$, and $34 \%$ increase over Pungsannamul. In contrast, the six LIP (PE718, PE828, PE1466, PE1552, PE3378, and PE3386) mutant lines showed lower mean values of inorganic $\mathrm{P}\left(0.54,0.53,0.52,0.38,0.57\right.$, and $\left.0.60 \mathrm{~g} \mathrm{~kg}^{-1}\right)$, corresponding to $40,41,42,58,37$, and $33 \%$ decrease compared to Pungsannamul (Table 2). Three LIP mutant lines (PE718, PE828, and PE1552) showed very low variation in inorganic $\mathrm{P}$ among the individual seeds for each line. This finding suggests that $\mathrm{M}_{4}$ plants of these lines might be fixed to homozygosity. However, the other three LIP (PE1466, PE3378, and PE3386) and four HIP (PE379, PE432, PE2205, and PE2503) mutant lines showed greater variation in inorganic P content per seed, suggesting that these lines may be heterozygous at the locus of interest or that the relevant traits might be controlled by two loci. Therefore, next generations of these lines will be carried forward to obtain homozygosity. Comparisons of the mutant lines (HIP and LIP) with Williams 82 $\left(0.75 \mathrm{~g} \mathrm{~kg}^{-1}\right)$ gave similar results to those with Pungsannamul (Table 2).

Wilcox et al. (2000) identified two soybean mutants with high inorganic seed P, M153 and M766. $\mathrm{M}_{6}$ progeny of M153 varied in inorganic $\mathrm{P}$ content from 2.34 to $4.41 \mathrm{~g} \mathrm{~kg}^{-1}$ and $\mathrm{M} 766$ had $1.21-3.84 \mathrm{~g} \mathrm{~kg}^{-1}$, compared to the cultivar Athow $\left(0.74 \mathrm{~g} \mathrm{~kg}^{-1}\right.$ inorganic P). They predicted that $75 \%$ of the total $\mathrm{P}$ in seeds of soybean lpa mutants is available $\mathrm{P}$, whereas nonmutant soybean have approximately $25 \%$ available $\mathrm{P}$ (Wilcox et al. 2000). Similarly, the earlier reported lpa mutant lines in corn, barley, and rice showed more than a $50 \%$ reduction of phytate level (Raboy and Gerbasi 1996; Ertl et al. 1998; Larson et al. 1998; Larson et al. 2000). Several reports of seed phosphorus fractions in lpa mutants indicate that reduction in phytate contents are largely associated with increases in inorganic P (Raboy 2007), suggesting that HIP mutants may contain low phytate levels.
In seeds, phytate synthesis pathway is complex and non-linear (Raboy 2007). The lpa mutant line that we used as a control, 5601T-1316, showed an average inorganic $P$ content of $2.49 \mathrm{~g} \mathrm{~kg}^{-1}$ (Table 2). Increase of inorganic P content in 5601T-1316 was due to homozygosity for double mutation in lpal and lpa2 genes (lpal-a and lpa2-a alleles). However, a single mutant, lpal or lpa 2 showed slight increase in inorganic $\mathrm{P}$ level compared to wildtype control (Gillman et al. 2009). Therefore, although the HIP lines showed less inorganic P than that of 5601T-1316, we suggest that these mutants might have mutation(s) in either one of lpa genes or mutation at different locus that encodes another enzyme involved in phytate synthesis pathway. Thus, crosses between HIP lines and wild-type control will be carried out subsequently after the selection of homozygous lines to identify the molecular basis of these HIP mutants and understand the biosynthetic pathway of phytate.

Acknowledgments This work was carried out with the support of "Cooperative Research Program for Agriculture Science \& Technology Development (Project No. PJ01108702)" Rural Development Administration, Republic of Korea.

\section{References}

Adeola O, Lawrence BV, Sutton AL, Cline TR (1995) Phytase-induced changes in mineral utilization in zinc-supplemented diets for pigs. J Anim Sci 73: 3384-3391

Almeida FN, Sulabo RC, Stein HH (2013) Effects of a novel bacterial phytase expressed in Aspergillus oryzae on digestibility of calcium and phosphorus in diets fed to weanling or growing pigs. J Anim Sci Biotechnol 4: 8

Bilyeu KD, Zeng P, Coello P, Zhang ZJ, Krishnan HB, Bailey A, Beuselinck PR, Polacco JC (2008) Quantitative conversion of phytate to inorganic phosphorus in soybean seeds expressing a bacterial phytase. Plant Physiol 146: 468-477

Brinch-Pedersen H, Sørensen LD, Holm PB (2002) Engineering crop plants: getting a handle on phosphate. Trends Plant Sci 7: 118-125

Brown KH, Solomons NW (1991) Nutritional problems of developing countries. Infect Dis Clin North Am 5: 297-317

Chappell AS, Scaboo AM, Wu X, Nguyen H, Pantalone VR, Bilyeu KD (2006) Characterization of the MIPS gene family in Glycine max. Plant Breed 125: 493-500

Eklund A (1975) The contents of phytic acid in protein concentrates prepared from nigerseed, sunflower seed, rapeseed and poppy seed. Ups J Med Sci 80: 5-6

Ertl DS, Young KA, Raboy V (1998) Plant genetic approaches to phosphorus management in agricultural production. J Environ Qual 27: 299-304

Fredlund K, Asp N-G, Larsson M, Marklinder I, Sandberg A-S (1997) Phytate reduction in whole grains of wheat, rye, barley and oats after hydrothermal treatment. J Cereal Sci 25: 83-91

Gillman JD, Pantalone VR, Bilyeu K (2009) The low phytic acid phenotype in soybean line CX1834 is due to mutations in two homologs of the maize low phytic acid gene. Plant Genome 2: 179-190

Hande PA, Mondal S, Badigannavar AM, DSouza SF (2013) Genetic variability of phytic acid phosphorus and inorganic phosphorus in cultivated groundnut (Arachis hypogaea L.). Plant Genet Resour 11: 190-195

Hitz WD, Carlson TJ, Kerr PS, Sebastian SA (2002) Biochemical and molecular characterization of a mutation that confers a decreased raffinosaccharide and phytic acid phenotype on soybean seeds. Plant 
Physiol 128: 650-660

Klein M, Burla B, Martinoia E (2006) The multidrug resistance-associated protein (MRP/ABCC) subfamily of ATP-binding cassette transporters in plants. FEBS Lett 580: 1112-1122

Larson SR, Rutger JN, Young KA, Raboy V (2000) Isolation and genetic mapping of a non-lethal rice (Oryza sativa L.) low phytic acid 1 mutation. Crop Sci 40: 1397-1405

Larson SR, Young KA, Cook A, Blake TK, Raboy V (1998) Linkage mapping of two mutations that reduce phytic acid content of barley grain. Theor Appl Genet 97: 141-146

Lee C, Choi M-S, Kim H-T, Yun H-T, Lee B, Chung Y-S, Kim RW, Choi HK (2015) Soybean [Glycine max (L.) Merrill]: Importance as a crop and pedigree reconstruction of Korean varieties. Plant Breed Biotechnol 3: $179-196$

Makkar HPS, Becker K (2009) Jatropha curcas, a promising crop for the generation of biodiesel and value-added coproducts. Eur J Lipid Sci Technol 111: 773-787

Maroof MAS, Glover NM, Biyashev RM, Buss GR, Grabau EA (2009) Genetics basis of the low-phytate trait in the soybean line CX1834. Crop Sci 49: 69-76

Mendoza C, Viteri FE, Lönnerdal B, Raboy V, Young KA, Brown KH (2001) Absorption of iron from unmodified maize and genetically altered, lowphytate maize fortified with ferrous sulfate or sodium iron EDTA. Am J Clin Nutr 73: 80-85

Mendoza C, Viteri FE, Lönnerdal B, Young KA, Raboy V, Brown KH (1998) Effect of genetically modified, low-phytic acid maize on absorption of iron from tortillas. Am J Clin Nutr 68: 1123-1127

Oltmans SE, Fehr WR, Welke GA, Cianzio SR (2004) Inheritance of low- phytate phosphorus in soybean. Crop Sci 44: 433-435

Platt SR, Clydesdale FM (1987) Interactions of iron, alone and in combination with calcium, zinc, and copper, with a phytate-rich, fiber-rich fraction of wheat bran under gastrointestinal pH conditions. Cereal Chem 64: 102105

Raboy V (2002) Progress in breeding low phytate crops. J Nutr 132: 503S$505 \mathrm{~S}$

Raboy V (2007) Seed phosphorus and the development of low-phytate crops. In: Turner BL, Richardson AE, Mullaney EJ (eds.) Inositol phosphates: linking agriculture and the environment. $\mathrm{CAB}$ international, Wallingford, Oxfordshire, UK, pp 111-132

Raboy V, Gerbasi P (1996) Genetics of myo-inositol phosphate synthesis and accumulation. In: Biswas BB, Biswas S (eds.) Myo-inositol phosphates, phosphoinositides, and signal transduction. Plenum Press, New York, pp $257-285$

Raboy V, Gerbasi PF, Young KA, Stoneberg SD, Pickett SG, Bauman AT, Murthy PPN, Sheridan WF, Ertl DS (2000) Origin and seed phenotype of maize low phytic acid 1-1 and low phytic acid 2-1. Plant Physiol 124: $355-368$

Shi J, Wang H, Schellin K, Li B, Faller M, Stoop JM, Meeley RB, Ertl DS, Ranch JP, Glassman (2007) Embryo-specific silencing of a transporter reduces phytic acid content of maize and soybean seeds. Nat Biotechnol 25: 930-937

Walker DR, Scaboo AM, Pantalone VR, Wilcox JR, Boerma HR (2006) Genetic mapping of loci associated with seed phytic acid content in CX1834-1-2 Soybean. Crop Sci 46: 390-397

Wilcox JR, Premachandra GS, Young KA, Raboy V (2000) Isolation of high seed inorganic P, low-phytate soybean mutants. Crop Sci 40: 1601-1605 